\title{
CFD ANALYSIS OF THE TRACTOR PROPULSION CONCEPTS FOR AN INVERTED JOINED WING AIRPLANE
}

\author{
Adam Dziubiński \\ Łukasiewicz Research Network - Institute of Aviation \\ Al. Krakowska 110/114, 02-256 Warsaw \\ Adam.Dziubinski@ilot.lukasiewicz.gov.pl•ORCID 0000-0002-2485-9843
}

\begin{abstract}
Efficiency is a crucial parameter for an airplane to reduce both cost of operations and emission of pollutants. There are several airplane concepts that potentially allow for increasing the efficiency. A few of them were not investigated thoroughly enough yet. The inverted joined wing configuration, with the upper wing in front of the lower one is an example of such concept. Therefore, a project consisting of development of an experimental scaled demonstrator, and its wind tunnel and flight testing, was undertaken by consortium: Institute of Aviation, Warsaw University of Technology, Air Force Institute of Technology and a MSP company. Results led to a conclusion, that the inverted joined wing configuration allows to build an airplane with excellent performance, but its advantage against the conventional airplane is marginal because of large trimming drag of the configuration with relatively high position of the thrust vector in pusher configuration. It was applied because the demonstrator was a flying model of manned airplane and the tractor configuration would affect the pilot's field of observation. However, in case of the UAV, this reason becomes insignificant. Therefore two configurations of tractor propulsion were tested to see, if their performance is better than the performance of original design.
\end{abstract}

Keywords: CFD, joined wing, tractor propulsion.

\section{INTRODUCTION}

The joined wing configuration is considered as a candidate for future airplane due to several potential advantages resulting from the mass and induced drag reduction. It is an unconventional airplane configuration, consisting of two lifting surfaces, similar in terms of area and span. One of them is located at the top or above the fuselage, whereas the second is located at the bottom. Moreover, one of the lifting surfaces is attached in front of the airplane's center of mass, whereas the second is attached significantly behind it. Both lifting surfaces join each other either directly or with the application of wing tip plates, creating a box wing.

Application of this concept was described for the first time by Prandtl in 1924 [1]. The concept was further developed by Wolkovitch [2] and many others. Researchers in Poland got interested in this concept in the early eighties $[3,4]$. Their works led to the conclusion, that front wing of the joined-wing airplane should be designed as a high-wing, and the aft one as a low-wing configuration $[5,6]$. 
Joined wing configuration is difficult to design due to the strong aerodynamic coupling [7] and static indeterminacy. Therefore, a dedicated research program was undertaken to explore its properties $[8,9]$, utilizing the previous experience in optimisation [10-15] and the UAV flight testing [16-19]. The Institute of Aviation was chosen as a leader of this effort because of its specialization [20] and its previous experiences in general aviation [21].

In course of this project, the flying unmanned demonstrator was built to explore the flight properties of this configuration [22]. Its flight characteristics were thoroughly investigated [23, 24] with application of the data from both: CFD analysis and wind tunnel measurements $[25,26]$. Simultaneously, further multicriterial aerodynamic optimisation was conducted to explore the borders of this configuration's performance potential [27]. Finally, the software for multidisciplinary optimisation was developed and applied to introduce also the structural analysis into consideration [28, 29]. As a result, it appeared that the inverted joined wing configuration allows to build an airplane with excellent performance, but its advantage against the conventional airplanes is marginal [30]. This result was obtained mostly because of the large trimming drag of configuration applied. Four sources of the trimming drag were identified in the flying demonstrator $[31,32]$ :

- Negative value of the pitching moment obtained for most of the high performance airfoils developed so far,

- The need for stability, which implies the requirement of CG position in front of the point of neutral stability,

- The large lift coefficient close to the wingtips of the front wing due to application of the front-aft wing tip plates,

- High position of the thrust vector line.

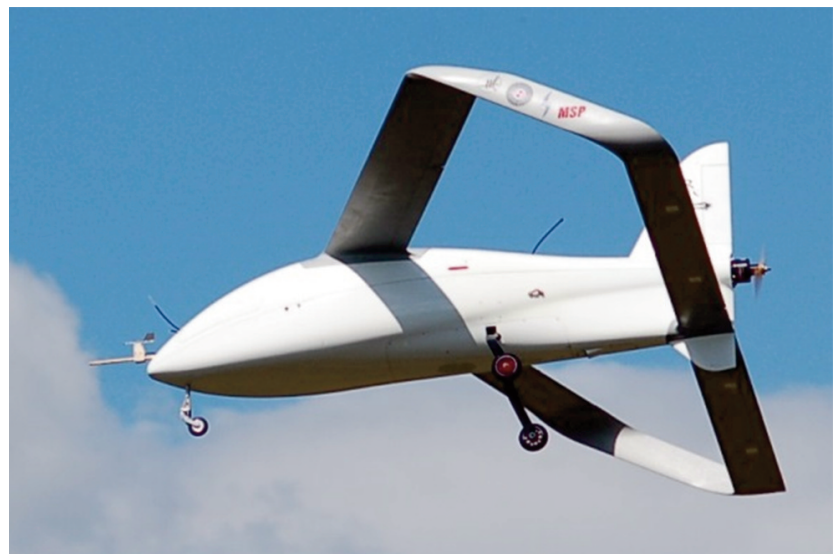

Fig. 1. Original configuration of ILX-32 MOSUPS.

First of those sources is difficult to avoid, since the airfoils with the positive pitching moment usually have either a poor performance or other disadvantageous flow characteristics. Second is unavoidable in the airplanes without fly-by wire system and an artificial stability augmentation. Third one seems to be a natural consequence of application of the joined wing configuration. Connection between the front and aft wings decreases induced drag but shifts the area of maximum lift into the wing tip direction. With certain CG position it will always result with an additional negative pitching moment. Therefore, the position of thrust vector seems to be the only design parameter that can easily improve the pitching moment and decrease the trimming drag. Therefore an application of conventional tractor configuration was considered to investigate the effect of propeller wake on the airplane balance. Both attempts are presented in this paper. After the first, introductive part, the second contains details of both analysed 
configurations, and the third presents applied methodology. The fourth and fifth sections show the results of CFD analyses performed for both configurations. Finally the sixth section summarizes and concludes the obtained results.

\section{PROPULSION SYSTEMS CONFIGURATIONS CONSIDERED}

\section{Single-engine tractor configuration}

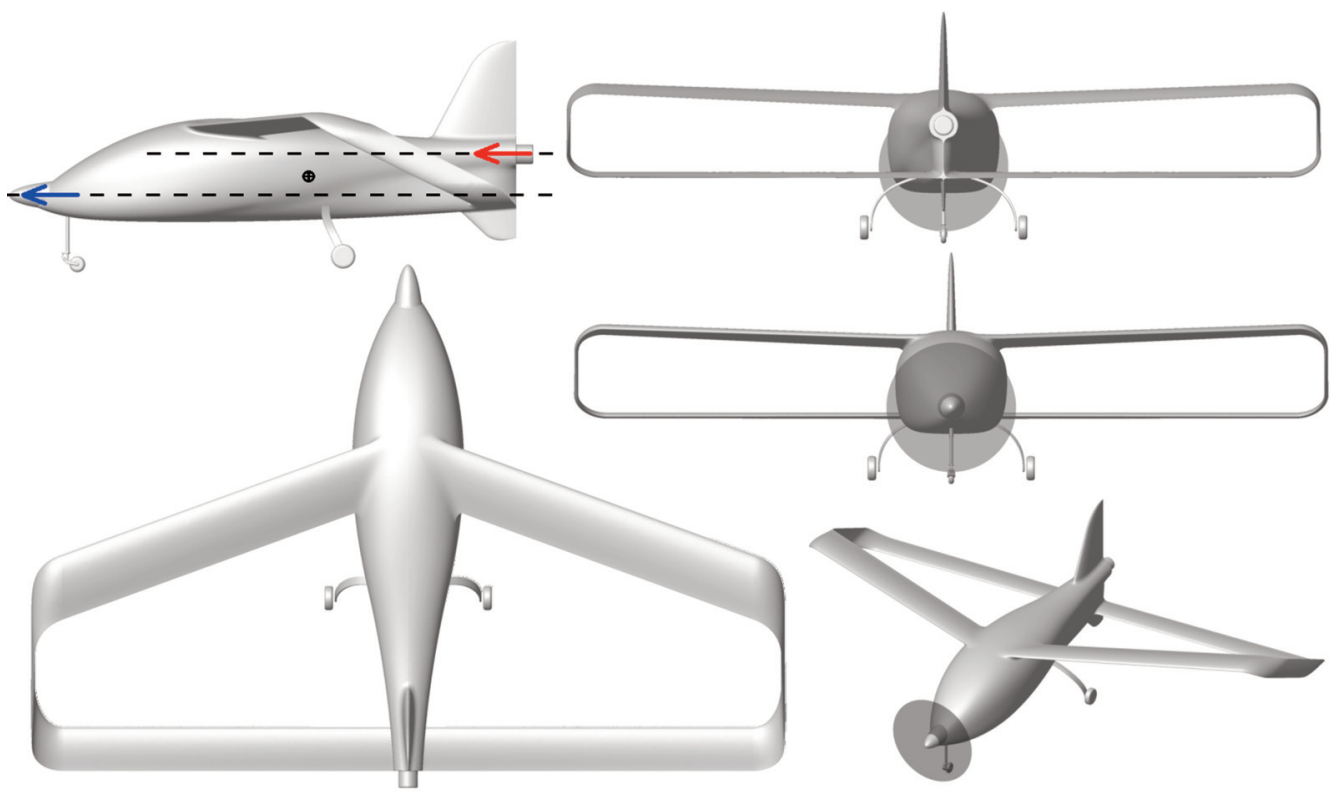

Fig. 2. Single-engine tractor configuration. Red arrow represents the thrust vector in original configuration, blue arrow represents the thrust in tractor configuration

Original project assumed, that the ILX-32 MOSUPS will be used as a dynamically similar model of manned airplane for four persons. This assumption defined the propulsion configuration. The pilot would have to sit behind the front wing if tractor configuration was applied. This would significantly constrain his field of observation. Therefore, the pusher configuration was applied. On the other hand, an application of existing ILX-32 model as an unmanned aerial vehicle does not impose any requirements for pilot visibility. Moreover, the internal equipment arrangement of the model allows for wider reconfigurations than a manned airframe, so the tractor configuration could be applied. It would allow to locate the thrust axis at the same level as the center of gravity or even below (Fig. 2), after a small extension of nose leg of the landing gear. As a result, the negative effect of thrust on the pitching moment and the aircraft's balance should be avoided.

\section{Multi-engine tractor configuration}

The multi-engine tractor configuration consists of four motors and propellers installed in the nacelles attached to the leading edge of the front wing. It was supposed to solve the problem of excessive pitching moment and the trim drag through the increase of air velocity around the front wing. Significant part of the front wing is located in front of the airplane's center of mass. Therefore, the increased air velocity about 
this section should also increase the lift in front of the center of mass. As a result, the positive pitching moment resulting from this accelerated flow should balance the negative pitching moment resulting from the thrust vector acting high above the center of mass. Moreover the nacelles were designed with a significant positive incidence angle so the thrust vector axis eccentricity was reduced. The incidence angle of each nacelle was equal to the local incidence angle of the wing's airfoil.

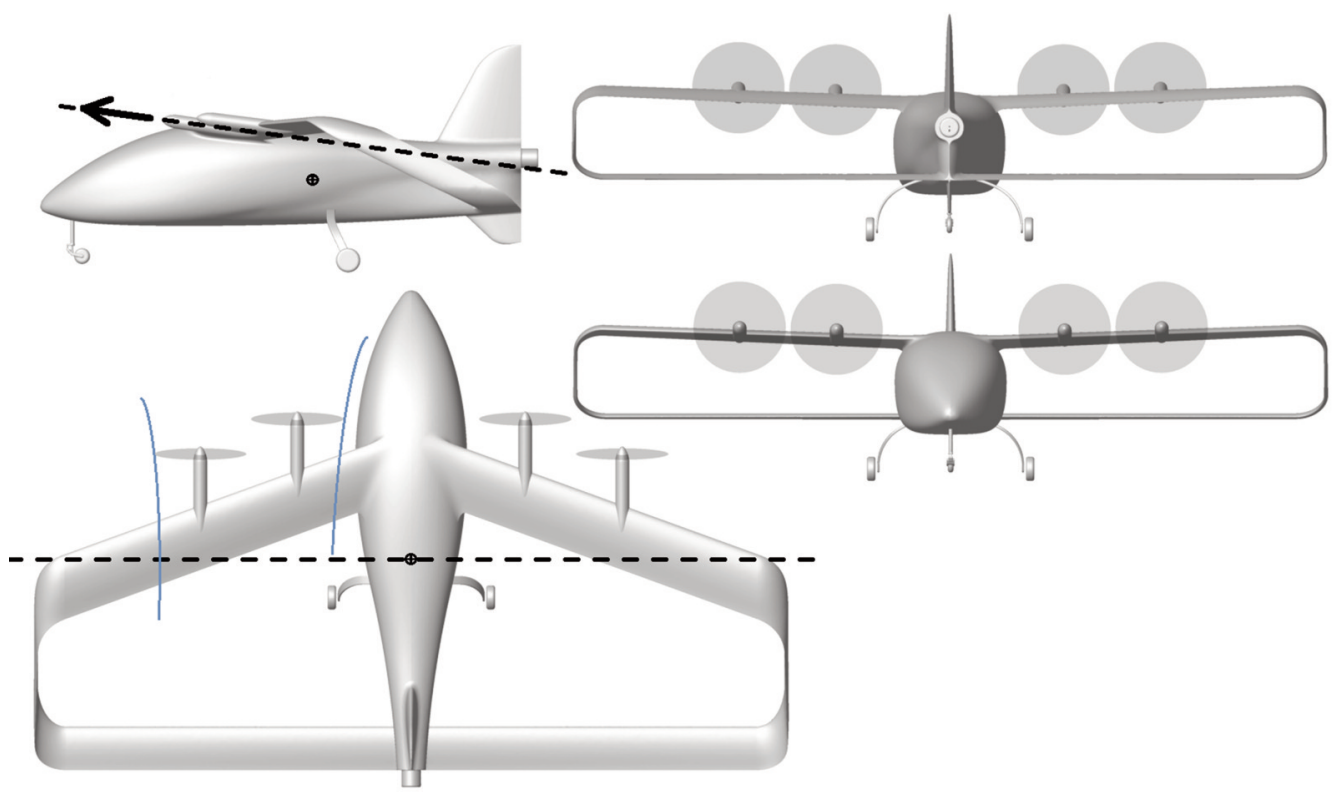

Fig. 3. Multi-engine configuration.

\section{METHODOLOGY}

The CFD simulation was conducted using finite volumes method of solving the Navier-Stokes equations. A commercial software, ANSYS Fluent $<\mathrm{tm}>$ was chosen for this task. Due to complexity of aircraft geometry, structured mesh was not feasible, hence, the unstructured tetrahedral mesh was created. ICEM CFD, a tool within the ANSYS suite was used for mesh generation. This choice was caused by the ICEM's powerful and robust method of prismatic mesh creation. The prismatic elements are pushed between the walls and the previously generated tetrahedral mesh, so even such a complicated shape, as the joined wing aircraft, can be surrounded by a well-defined boundary layer mesh. During this process the border elements could be squished, so the tetrahedral elements are constantly smoothed and re-meshed, if necessary.

The mesh describes a half of the airplane, assuming symmetry of the airplane and the flow. This approach was drawn from the assumption, that the aerodynamic characteristics will be investigated only as a function of angle of attack (AoA), but also it radically speeds up the calculation and demands less of the storage capability.

In described calculations, the Menter K- $\omega$ SST turbulence model was used. This model demands a mesh with $Y+$ criterion size of 1 , so the boundary mesh parameters have been set to fulfil this requirement. These settings allowed the solver to simulate even laminar bubbles areas on the wing surface.

In order to simulate the influence of propeller wake, a simplified approach of using the actuator discs instead on propellers has been employed. The pressure jump was a result of necessary - or assumed - 
thrust value, and was constant along the radius of propeller. This approach is simplified enough to enable calculation of various cases, without detailed knowledge on the propeller (rotational speeds, airfoils, chords and angle of inclination distribution) thus avoiding the usual complications and extensive requirements of rotating propeller simulation.

As a result, the pressure distribution along the wing was modified due to induced velocity of the propeller wake, but without influence of the unknown swirl (axial rotation of the propeller stream, induced by the propeller blade's drag). This pressure distribution was then integrated to investigate the flow velocity increase net effect on aerodynamic characteristics. Then the thrust vector was added to investigate the equilibrium of the airplane.

\section{RESULTS FOR SINGLE-ENGINE TRACTOR CONFIGURATION}

The single-engine configuration was investigated for three thrust configurations - the maximum thrust (CLIMB), the cruise thrust (CRUISE) and the idle thrust (GLIDE). The results are presented in figures 4-5. Application of the tractor propeller causes the increase of both lift and drag. The increase of lift is proportional to the angle of attack with the smallest value in the point of lift equal to zero. On the other hand the increase of drag is constant in the whole range of angle of attack. Therefore, the increase of drag is caused by the flow around the nose part of the fuselage, which is not influenced by the angle of attack in the propeller stream.
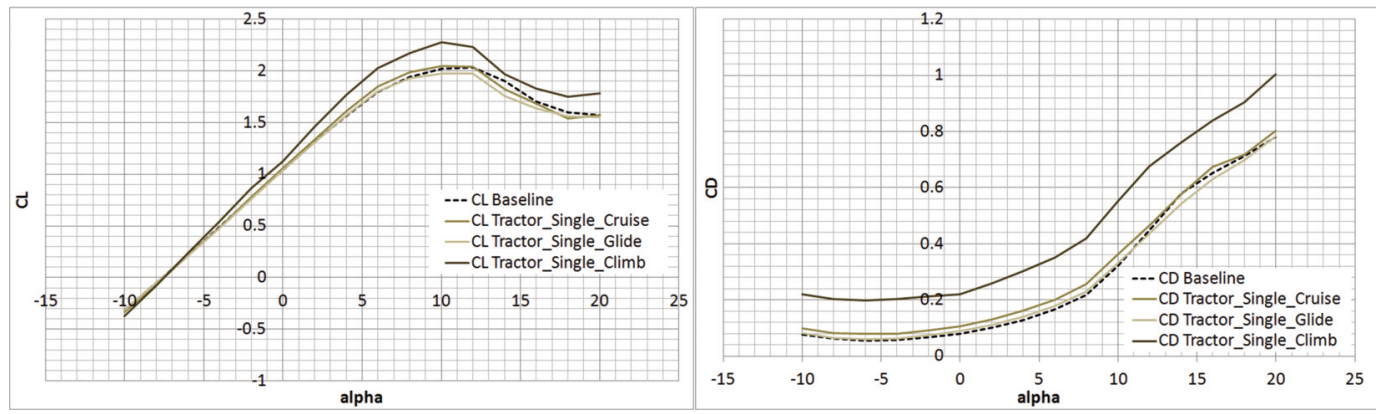

Fig. 4. Lift and drag coefficients as a function of angle of attack compared with characteristics of the baseline ILX-32 (thrust vector subtracted in cruise and climb configuration).
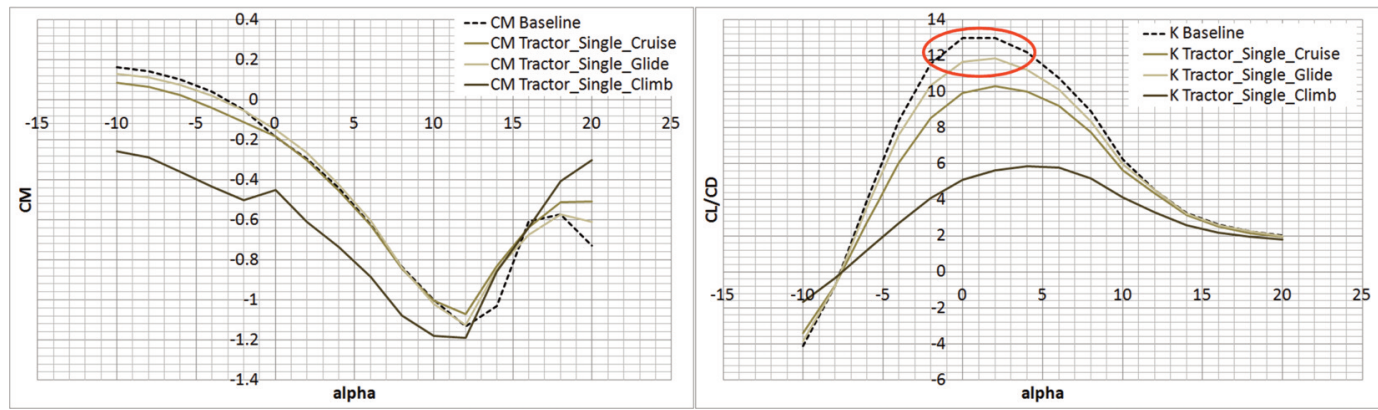

Fig. 5. Pitching moment coefficient and lift/drag ratio as a function of angle of attack compared with characteristics of the baseline ILX-32 (thrust vector subtracted in cruise and climb configuration).

Unfortunately the tractor propulsion makes the pitching moment more negative, probably because of the increased velocity around central part of the aft wing, increased drag of the fuselage nose and increased drag of the landing gear. In the worst case, when the thrust is set to CLIMB, the pitching 
moment does not cross the line of $\mathrm{Cm}=0$. As a result, the new configuration still needs the elevator deflection for balance. Moreover each thrust configuration is characterised by the reduced lift/drag ratio. In case of the CLIMB configuration, lift/drag ratio falls to the value of 6 .

Decrease of the lift/drag ratio in the GLIDE configuration is caused by modification of the fuselage shape and extension of the front leg of the landing gear. In particular, the extension of front landing gear generates a significant increase of drag since the leg has cylindrical shape and the flow velocity vector is almost perpendicular to its axis for whole operational range of the AoA (angle of attack) (Fig. 6.).

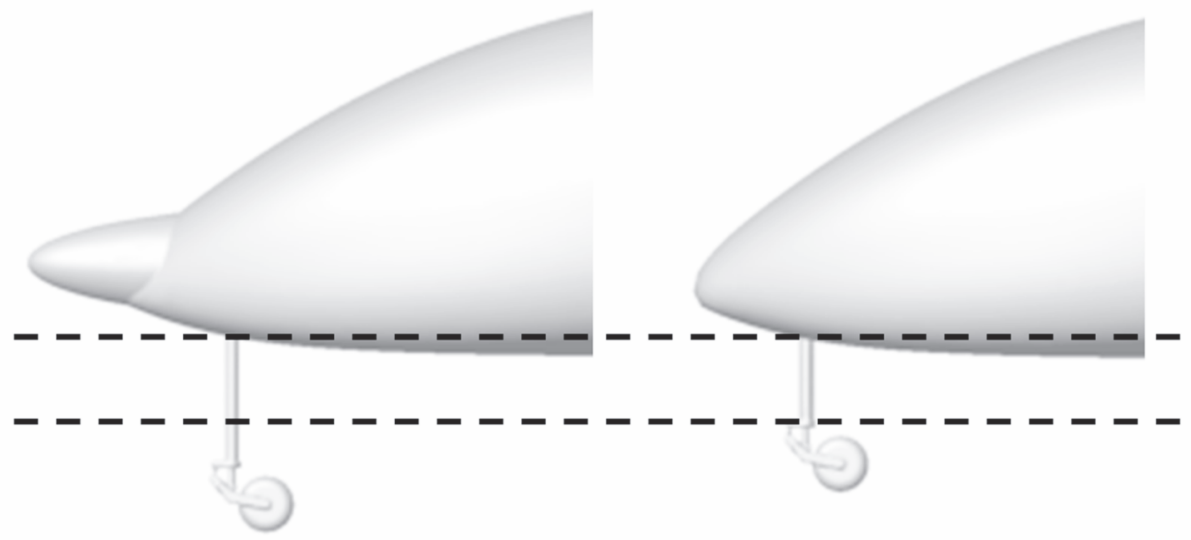

Fig. 6. Modification of the nose part of the fuselage and the landing gear.

Effect of geometry modifications on the aerodynamic characteristics of isolated fuselage and landing gear are shown in Fig. 7. In case of the fuselage, the difference is visible only close to the stall angle.

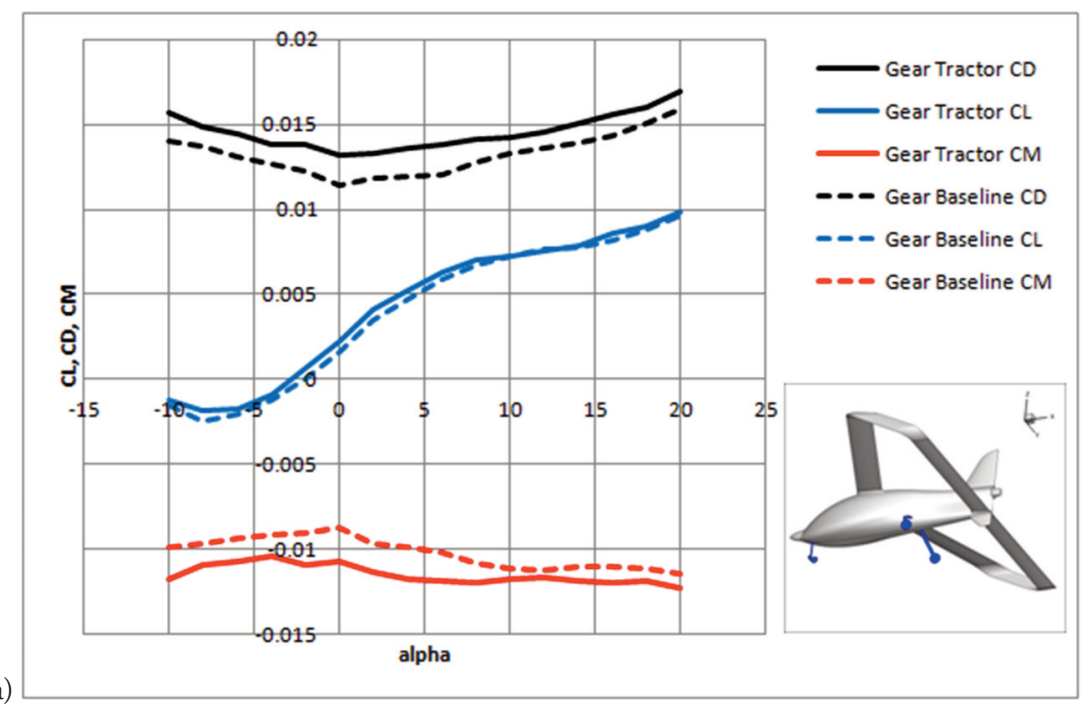




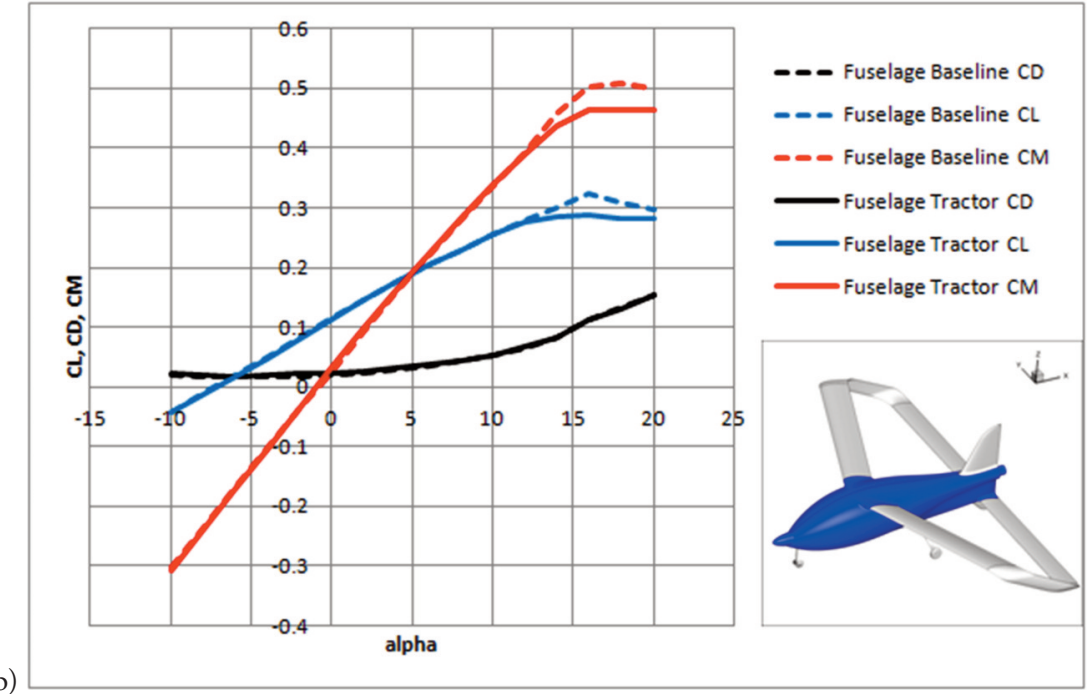

Fig. 7. Effect of the modifications of the landing gear and fuselage on their aerodynamic characteristics in the GLIDE configuration.

Modified fuselage stalls earlier and generates smaller CLmax. On the other hand effect of the front leg of the landing gear is clearly visible in the whole range of angles of attack. The drag increase of the landing gear is largest for the cruise angle of attack when the low surface of the fuselage is parallel to the undisturbed velocity direction.

In the case of CLIMB configuration (Fig. 8.) these effects together with increased velocity around the central part of the aft wing are capable to overcome the positive pitching moment caused by the thrust eccentricity. As a result, the airplane does not achieve the equilibrium for any angle, in the investigated range, without elevator deflection. In case of the CRUISE configuration (Fig. 9.), the airplane achieves the equilibrium, but it is achieved for very low angle of attack $\left(\right.$ AoA $\left.\approx-4^{\circ} \ldots-5^{\circ}\right)$, well below the optimal values, in case of both the lift/drag ratio and the power factor.
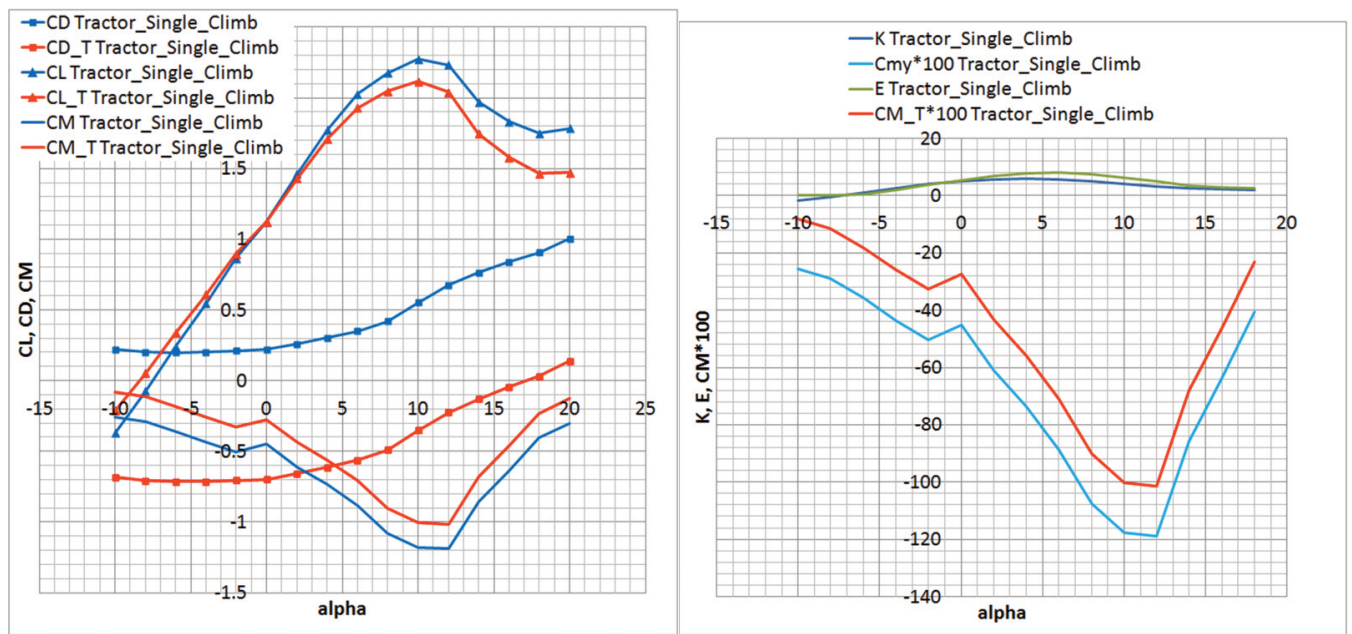

Fig. 8. Effect of the thrust set to CLIMB on the aerodynamic characteristics of the single-tractor configuration. 

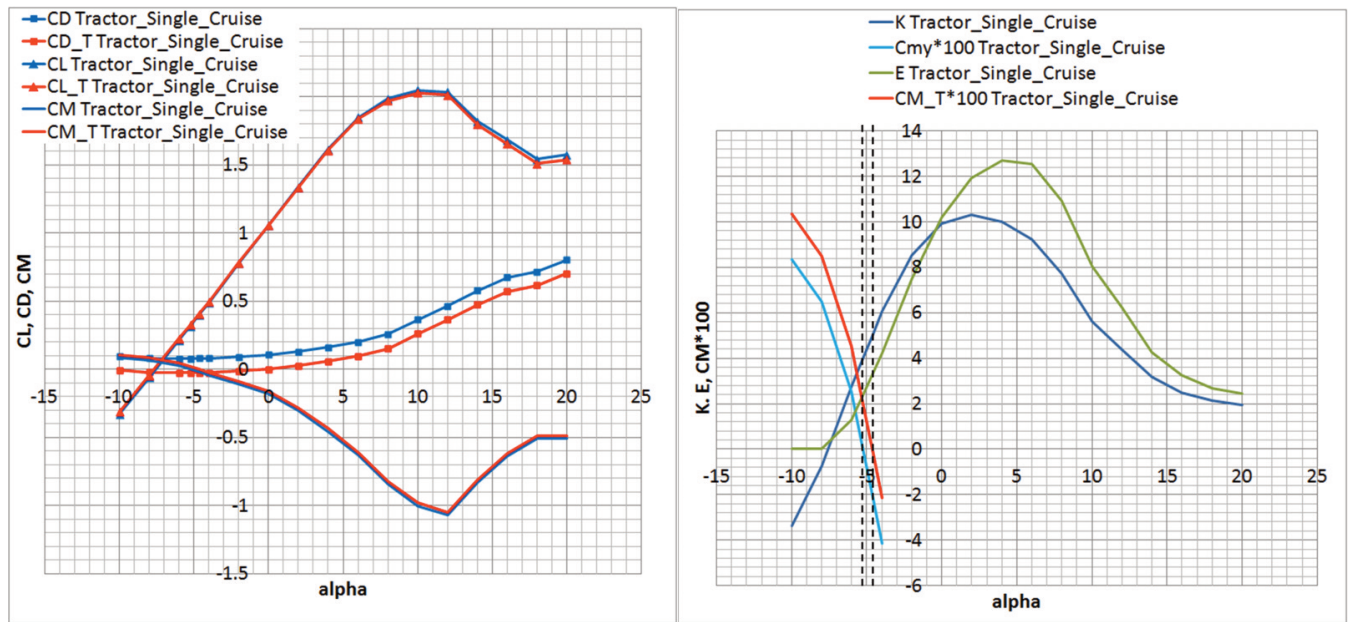

Fig. 9. Effect of the thrust set to CRUISE on the aerodynamic characteristics of the single-tractor configuration.
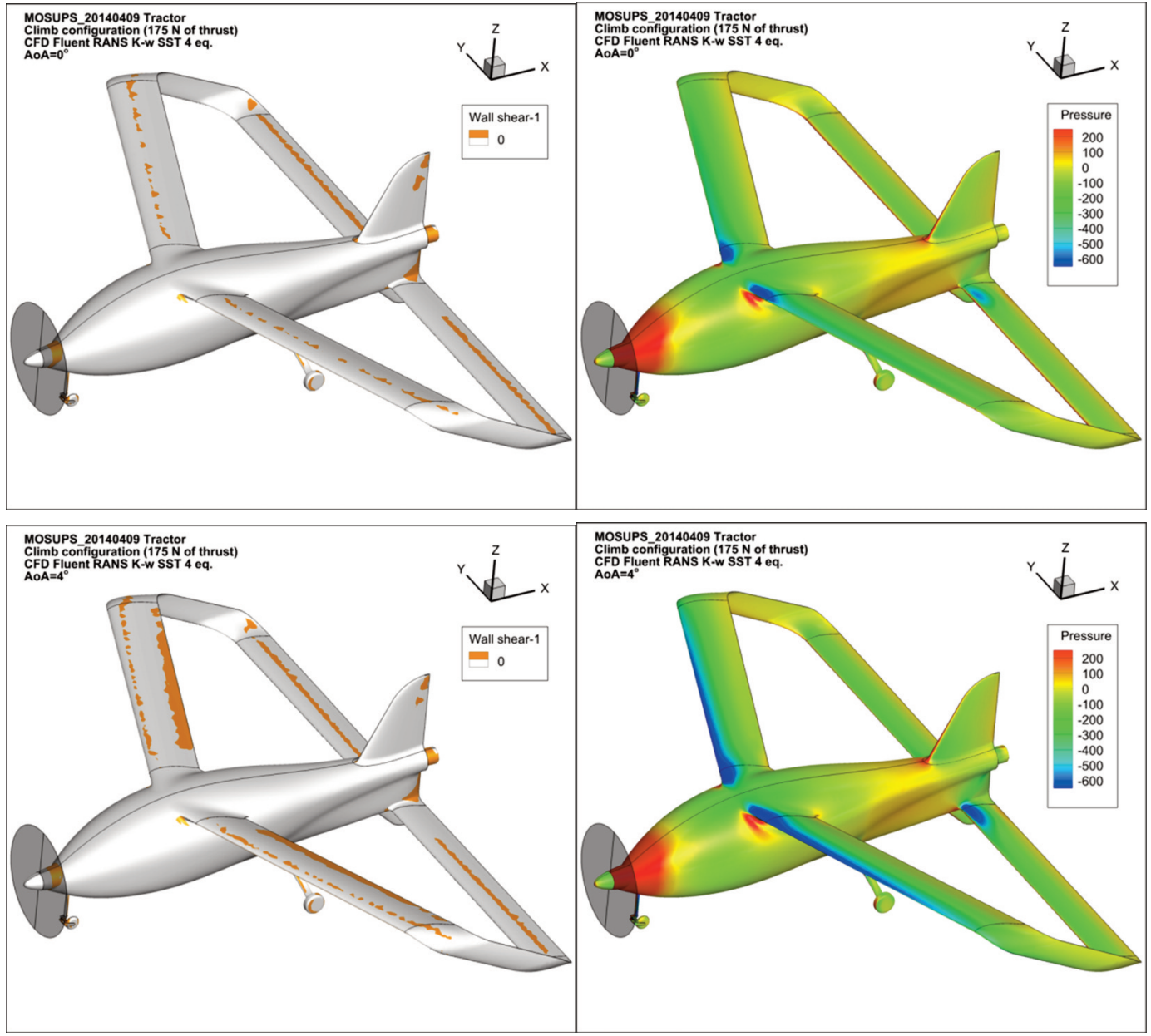


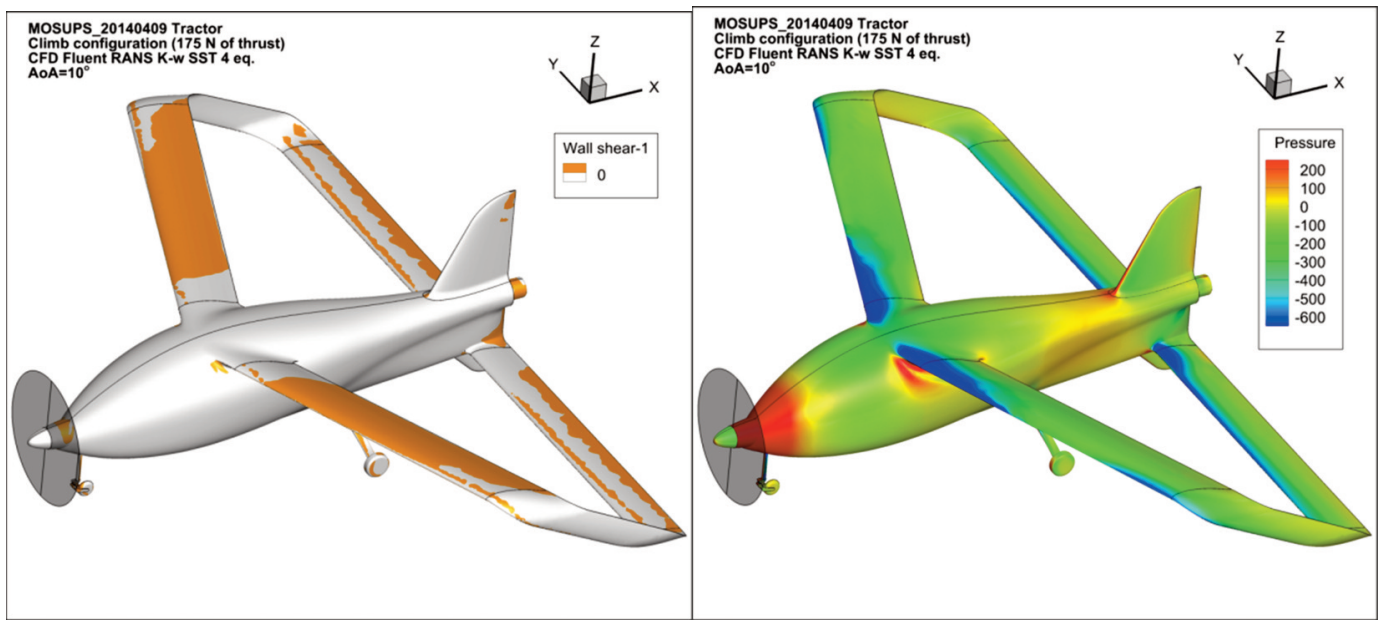

Fig. 10. Flow separation and pressure coefficients on the single-engine tractor configuration when the thrust is set for CLIMB.

The qualitative results are presented in Figure 10. The propeller stream influences a relatively narrow area of the front and aft wings. In both cases a local improvement of the flow is observed. The flow is locally attached for the higher angle of attack, the previously existing laminar bubble disappears and the pressure coefficient is still negative even at the stall angle. On the other hand a significant increase of pressure is observed on the fuselage, just behind the propeller, which influences both drag and the pitching moment of the airplane.

\section{RESULTS FOR THE MULTI-ENGINE TRACTOR CONFIGURATION}

Figure 11 shows a comparison of lift and drag coefficients between the multi-engine tractor configuration and the BASELINE (pusher) configuration. In both cases the thrust effect was accounted for, but the thrust vector was subtracted from the results. Indeed the increased velocity around the front wing increases the gradient of lift coefficient due to the increased lift on the front wing. Maximum value of the lift coefficient grows up to impressive value of 2.7 without high-lift devices extended. Unfortunately it is associated with the drag increase proportional to the angle of attack, with minimal value achieved, when the lift coefficient is equal to zero.
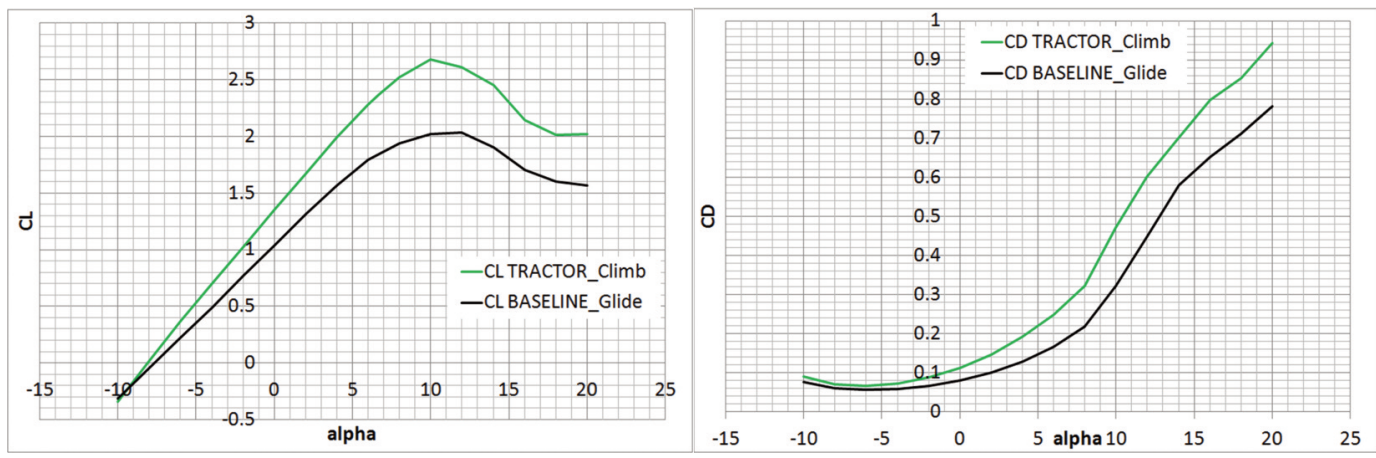

Fig. 11. Lift and drag coefficients for multi-engine configuration compared with baseline. 
Another issue is associated with the pitching moment characteristic, which is much flatter than in the case of baseline (Fig. 12.). The pitching moment achieves zero for AoA $\alpha \approx 7^{\circ}$, but for AoA $\alpha \approx-2^{\circ}$ stability is neutral. This suggests a very small stability margin for the cruising and perhaps even a negative for the maximum airspeed. It could be improved if the center of mass would be shifted forward, but then either the negative elevator extension should be applied or the AoA $(\mathrm{Cm}=0)$ would fall. The lift to drag ratio is only slightly smaller than in the case of baseline which is a positive tendency.
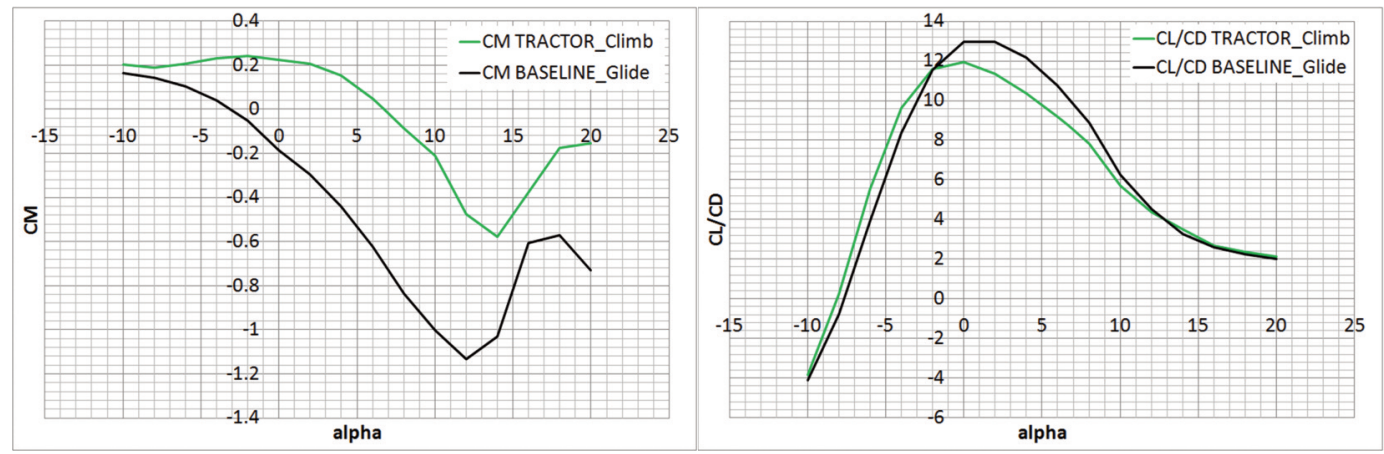

Fig. 12. Pitching moment coefficient and lift/drag ratio for multiengine configuration compared with baseline

The Figure 13 compares the airplane characteristics with thrust effect but with the thrust vector subtracted and added. As it can be seen from this plot, the airplane can obtain equilibrium in the useful range of AoA with propeller wake influence only if the thrust vector is subtracted. As a result in the real flight the elevator deflection is necessary so increase of the trim drag has to be expected. Together with the elevator deflection, necessary to improve longitudinal stability (mentioned in the previous paragraph), it would cancel all the advantages of this configuration. Because of this result, it was decided not to investigate the airplane in this configuration for the cruising conditions.

Qualitative results (Fig. 14.) show, that the propeller stream blows out laminar bubbles behind the propeller and keeps the flow attached to the front wing for increased angle of attack range. As a result, the front wing becomes more effective. That is probably why the maximum lift coefficient is increased at the expense of decreased stability.
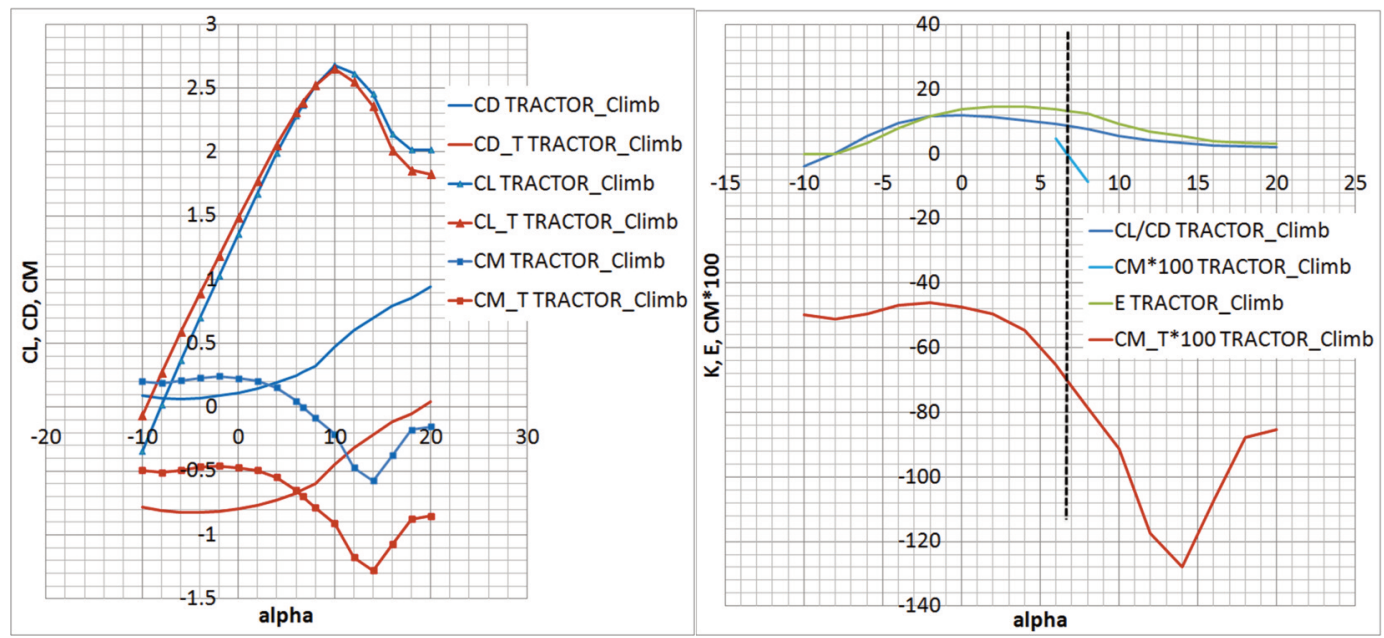

Fig. 13. Effect of the thrust on the characteristics of multi-engine tractor configuration. 


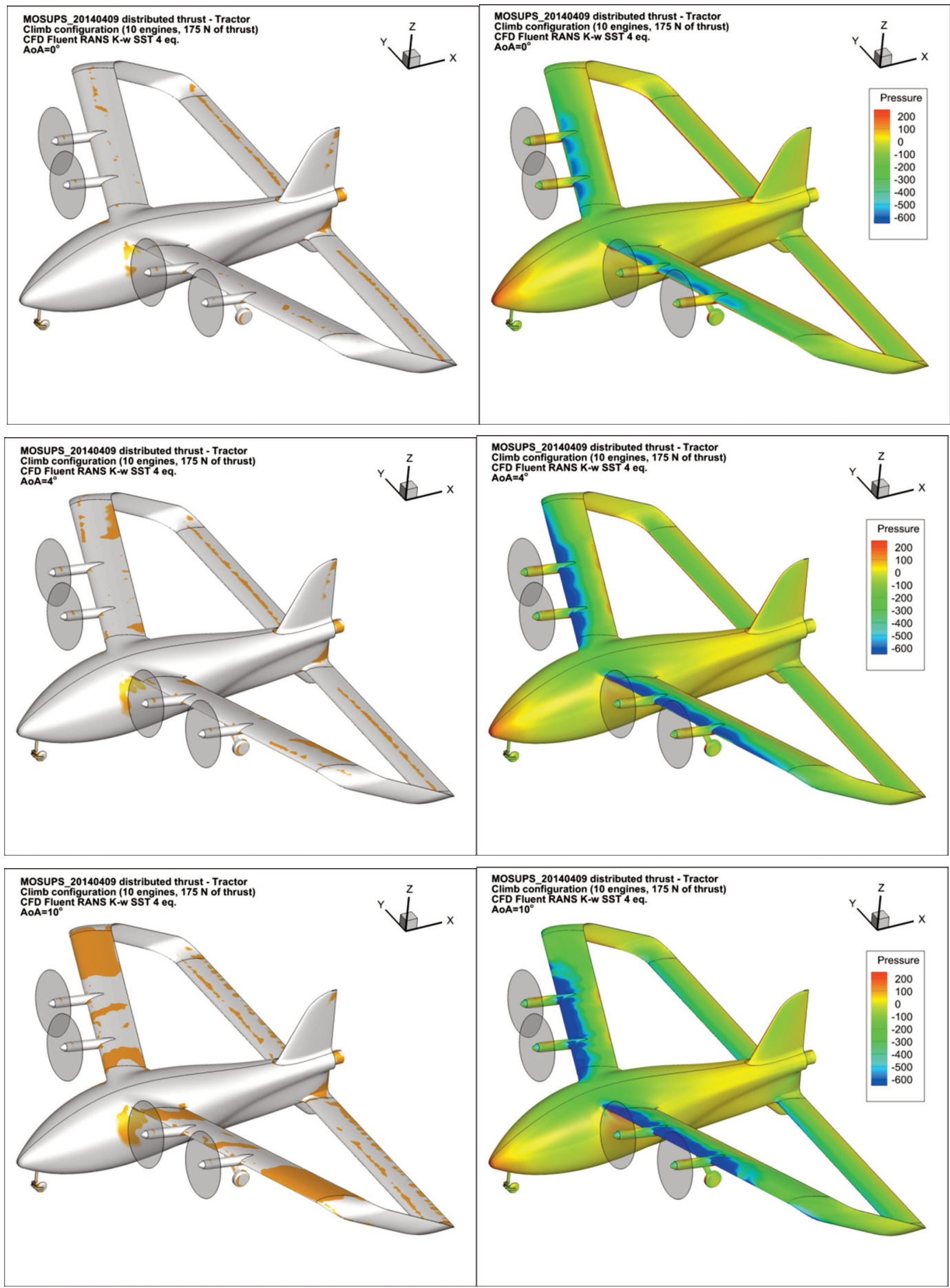

Fig. 14. Flow separation and pressure coefficients on the multi-engine tractor configuration when the thrust is set for CLIMB. 


\section{CONCLUSION}

The ILX-32 MOSUPS UAV plane was investigated with two tractor configurations of the propulsion system - single-engine and multi-engine. Analyses were performed with application of the ANSYS FLUENT software. The aerodynamic characteristics were calculated for the angle of attack range between $-10^{\circ}$ to $+20^{\circ}$ in selected thrust settings (named: GLIDE, CRUISE, CLIMB).

In the single-engine tractor configuration, the application of tractor propeller increases the lift proportionally to the angle of attack. On the other hand the increase of drag is constant in whole range of the angle of attack. Increase of the drag is mainly caused by the increased drag of front leg of the landing gear and the nose of the fuselage. Unfortunately it also makes the pitching moment more negative. As a result, the airplane cannot be balanced for the CLIMB conditions without the elevator deflection. Each thrust setting, other than none, causes the loss of lift/drag ratio. For the CLIMB configuration it achieves only $\mathrm{CL} / \mathrm{CD}=6$. The elevator deflection is necessary also for the CRUISING configuration. Narrow areas of the front and aft wings are covered by the propeller stream which results with the flow improvement. Laminar bubbles are blown down in these areas and the flow is attached even at the high angle of attack. Also the pressure coefficient is more negative even for the stall angle. On the other hand, the pressure coefficient is significantly increased on the fuselage just behind the propeller.

In the multi-engine tractor configuration application of four engines on the leading edge of front wing resulted with significant increase of the lift and increase of the lift gradient. Maximum lift coefficient achieves the value of 2, without high lift devices extended. Unfortunately it also increases the drag. This increase is proportional to the angle of attack with minimum value for the lift coefficient equal to zero. As a result the lift/drag ratio is smaller than for the baseline only by about 1 and achieves the value of $\mathrm{CL} / \mathrm{CD}=12$. Unfortunately, improved flow around the front wing decreases stability margin of the airplane. That stability becomes almost neutral for the cruising angle of attack. Moreover, the application of moment, generated by the thrust, does not allow to obtain the equilibrium without elevator deflection.

After analysis of these results it was decided that neither of these configurations is satisfactory.

\section{ACKNOWLEDGEMENTS}

This work was supported by statute founds of the Institute of Aviation. The author wishes to thank Prof. Galiński for all his help and patience during the calculations and preparation of this paper.

\section{REFERENCES}

[1] Prandtl, L., 1924, „Induced drag of multiplanes”, NACA TN 182.

[2] Wolkovitch, J., 1986, „The joined wing - An overview”, Journal of Aircraft, 23(3), pp. 161-178.

[3] Danilecki, S., 1988, „The joined wing - advantages and disadvantages (I)”, Technika Lotnicza i Astronautyczna (Aerospace Technology), 9, pp. 4-6. (in Polish).

[4] Danilecki, S., 1988, „The joined wing - advantages and disadvantages (II)”, Technika Lotnicza i Astronautyczna (Aerospace Technology), 10, pp. 8-10. (in Polish).

[5] Galinski, C., 1992, „Results of Testing of Models of Joined-Wing Utility Class Aircraft”, SAE paper No. 921013.

[6] Mamla, P. and Galinski, C., 2009, “Basic Induced Drag Study of the Joined-Wing Aircraft”, Journal of Aircraft, 46(4), pp. 1438-1440.

[7] Goraj, Z., Kulicki, P. and Lasek, M., 1997, "Aircraft Stability Analysis For Strongly Coupled Aerodynamic Configuration”, Journal of Theoretical and Applied Mechanics, 35,(1), pp.137-158. 
[8] Galiński, C. and Hajduk, J., 2015, “Assumptions of the Joined Wing Flying Model Programme”, Transactions of Institute of Aviation, 1(238), pp. 7-21, Warsaw.

[9] Galinski, C., Hajduk J., Kalinowski M., Seneńko, K., 2013, “The Concept of the Joined Wing Scaled Demonstrator Programme”, in Proceedings of the CEAS'2013 conference, paper 146, pp. 244253, Linkoping.

[10] Stalewski, W., 2012, "Parametric Modelling of Aerodynamic Objects - The Key to Successful Design and Optimisation", Aerotecnica Missili e Spazio, 91(1/2), pp. 23-31.

[11] Stalewski, W. and Żółtak, J., 2012, "Optimisation of the helicopter Fuselage with Simulation of Main and Tail Rotor Influence", Proceedings of the ICAS Congress, Brisbane, Australia.

[12] Stalewski, W. and Żółtak, J., 2011, "Multi-objective and Multidisciplinary Optimisation of Wing for Small Aircraft", Proceedings of the CEAS Congress on disc, pp. 1483-1492. Venice, Italy.

[13] Goetzendorf-Grabowski, T., Mieloszyk, J. and Mieszalski, D., 2012, "MADO Software Package for High Order Multidyscyplinary Aircraft Design and Optimisation", 28th Congress of the International Council of the Aeronautical Sciences, ICAS 2012-1.9.4, Brisbane.

[14] Mieloszyk, J., 2011, "Handling Optimisation Problems on an Example of Micro UAV", Proceedings of the 3rd CEAS Air \& Space Conference.

[15] Kalinowski, M., 2015, "Structural optimisation of box wing aircraft", Archive of Mechanical Engineering, Vol. LXII, No. 1, pp. 45-60.

[16] Galiński, C., Bartkiewicz, P., Hajduk, J. and Lamers, P., 1997, "Results of the J-5 Marco Dynamic Similar Model Flight Tests Program”, SAE Paper No. 975551.

[17] Goraj Z., Szender M., 2004, "Flight tests of remote controlled aircraft on high angle of attack", Proceedings of VI Conference "Methods and Technology of Research in Aircraft Flight Tests", ITWL, pp. 143-153. Mragowo, Poland. (in Polish)

[18] Goraj, Z. and Szender, M., 2005, "Techniques and critical technologies applied for small and mini UAVs. State of the art and development perspectives", Transactions of the Institute of Aviation, 183, pp. 41-49.

[19] Goraj, Z., Kittmann, K., Voit-Nitschmann, R. and Szender, M., 2012, "Design and Integration of Flexi-Bird - a Low Cost Sub-Scale Research Aircraft for Safety and Environmental Issues", Proceedings of the ICAS Congress 2012, ICAS, Brisbane, Australia.

[20] Wisniowski, W., 2014, "Institute of Aviation Research Areas - Review and Conclusions", Transactions of Institute of Aviation, 2(235), Warsaw pp. 7-16, (in Polish).

[21] Wisniowski, W., 2014, "20 Years of Light Aircraft Safety Program”, Transactions of Institute of Aviation, 3(236), Warsaw pp. 7-25, (in Polish).

[22] Galinski, C., Hajduk, J. and Mieloszyk, J., 2014, "First Flight of the Inverted Joined-wing Demonstrator and Beyond",

https://w3.onera.fr/ceas-tcad2014/sites/w3.onera.fr.ceas-tcad2014/files/05_innovative_concepts_s2_b_ilot.pdf

[23] Lis M., Dziubiński A., Galinski C., Krysztofiak G., Ruchała P., Surmacz K., 2014, "Predicted Flight Characteristics of the Inverted Joined Wing Scaled Demonstrator", Proceedings of the ICAS'2014 conference, paper 552, St. Petersburg.

[24] Lis, M. and Galinski, C., 2015, "Predicted performance of the inverted joined wing scaled demonstrator", Aviation, Taylor and Francis, 19(3), pp. 123-132.

[25] Galiński, C., Krysztofiak, G., Miller, M., Ruchała, P., Kalski, M., Lis, M., Dziubiński, A., Bogdański, K., Stefanek, L. and Hajduk, J., 2018, "Wind Tunnel Tests of the Inverted Joined Wing and a comparison with CFD results", Aircraft Engineering and Aerospace Technology, 90(4), pp. 586-601. DOI: 10.1108/AEAT-11-2016-0195.R1.

[26] Dziubiński, A., Kuprianowicz, S., Surmacz, K., Galinski, C. and Żółtak, J., 2014, “The Joined Wing Scaled Demonstrator Results of CFD” Proceedings of the ICAS'2014 conference, 514 paper, St. Petersburg, 7-12 September. 
[27] Stalewski, W., 2015, "Aerodynamic Optimisation of Joined-Wing Aeroplane", Proceedings of 6th International Conference on Experiments/Process/System Modelling/Simulation//Optimisation, 6th IC-EpsMsO, Athens.

[28] Mieloszyk, J., 2017, "Practical problems of numerical optimization in aerospace sciences", Aircraft Engineering and Aerospace Technology, 89. 10.1108/AEAT-11-2016-0201.

[29] Kalinowski, M., 2016, "Aero-Structural Optimization of Joined-Wing Aircraft", READ conference, 12-14 September, Warsaw.

[30] Galinski, C., Hajduk, J., Dziubiński, A., Sieradzki, A., Lis, M. and Krysztofiak, G., 2015., "Progress in Inverted Joined Wing Scaled Demonstrator Programme", 5th CEAS Airespace Conference "Challenges in European Aerospace", Delft.

[31] Galiński, C., Stalewski, W., Lis, M. and Hajduk, J., 2016, "Overview of the Inverted Joined Wing Scaled Demonstrator Programme”, Proceedings of the ICAS'2016 conference paper 313, Daejeon.

[32] Mieloszyk, J., 2015, "Elaboration of Optimization Results on Full-Scale, Manned Version of MOSUPS Aircraft", unpublished report of Warsaw Institute of Technology (in Polish).

[33] Galiński, C., Sieradzki, A. and Kalinowski, M., 2016, "Propulsion Configuration Effect on Performance of an Inverted Joined Wing Airplane”, Journal of KONES, 23(3), pp. 135-143.

[34] Galiński, C., Lis, M. and Hajduk, J., 2017, "Electric Propulsion Concepts for an Inverted Joined Wing Airplane Demonstrator”, Energies, 10(6), no 762. DOI: 10.3390/en10060762.

[35] Sieradzki, A., Dziubiński, A. and Galiński, C., 2016, "Performance Comparison of the Optimized Inverted Joined Wing Airplane Concept and Classical Configuration Airplanes", Archive of Mechanical Engineering, 63(3), pp. 455-470.

\section{ANALIZA CFD KONCEPCJI NAPĘDU CIĄGNĄCEGO DLA SAMOLOTU W UKŁADZIE ODWRÓCONEGO PŁATA ZESPOLONEGO}

\section{Abstrakt}

Doskonałość jest kluczowym parametrem samolotu decydującym o redukcji kosztów operacyjnych i ilości emitowanych zanieczyszczeń. Istnieje kilka układów samolotu, które potencjalnie pozwalają na zwiększenie doskonałości. Kilku z nich nie przebadano dotychczas dogłębnie. Konfiguracja odwróconego płata zespolonego, gdzie przednie skrzydło w układzie górnopłata łączy się z tylnym w układzie dolnopłata, jest dobrym przykładem takiej koncepcji. Stąd, projekt mający na celu zbudowanie skalowanego demonstratora oraz przetestowanie w tunelu aerodynamicznym i w locie, został wykonany przez powołane do tego celu konsorcjum w składzie: Instytut Lotnictwa, Politechnika Warszawska, Instytut Techniczny Wojsk Lotniczych i firma MSP. Rezultaty dowiodły, że zastosowanie odwróconej konfiguracji połączonych skrzydeł pozwala na zbudowanie samolotu o doskonałych osiagach. Jego przewaga nad samolotami konwencjonalnymi jest jednak marginalna ze względu na duży opór konfiguracji w warunkach równowagi. Wynika on z konieczności zrównoważenia momentu od relatywnie wysoko położonego napędu. Napęd tak umiejscowiono ze względu na to, że demonstrator był modelem zdalnie sterowanym samolotu załogowego, w którym przedni napęd znacząco ograniczałby pole widzenia załogi. W przypadku bezzałogowca argument ten traci na istotności. Dlatego wybrano i przebadano obliczeniowo dwie konfiguracje napędu ciągnącego, sprawdzając, czy ich osiągi poprawią się względem oryginalnej konstrukcji.

Słowa kluczowe: obliczeniowa mechanika płynów, płat zespolony, napęd ciągnący. 